\title{
Novel Approach to the Rapid Differentiation of Common Prunus Allergen Species by PCR Product Melt Analysis
}

\author{
Gavin Nixon, Laurie Hall, Timothy Wilkes, Michael Walker, Malcolm Burns* \\ Science and Innovation, LGC Ltd., Teddington, England \\ Email: *malcolm.burns@lgcgroup.com
}

Received 2 August 2016; accepted 28 August 2016; published 31 August 2016

Copyright $@ 2016$ by authors and Scientific Research Publishing Inc.

This work is licensed under the Creative Commons Attribution-NonCommercial International License (CC

BY-NC).

http://creativecommons.org/licenses/by-nc/4.0/

(c) (1) (9) Open Access

\begin{abstract}
Food allergies represent a clear threat to the general health and wellbeing of those affected which place increasing pressure on food producers and regulatory authorities. Current analytical techniques typically find difficulties distinguishing between closely related Prunus species which include almond (Prunus dulcis), an EU listed allergenic species. This study describes a proof of principle real-time PCR approach utilising DNA melt analyses that targets the internal transcribed spacer (ITS) sequence to differentiate between a panel of Prunus test species. The method was successfully applied to the characterisation of a commercial paprika sample suspected of having being adulterated with almond, referred to the UK Government Chemist in 2015 in its advisory capacity. Subject to further validation work, the method appears to specifically amplify Prunus species and is capable of discrimination based on the resultant melt profiles. The developed method provides analysts with a simple and broad molecular tool to identify common Prunus species for food authenticity and allergen testing purposes. Initial development work demonstrates a promising approach with the potential to improve discrimination between Prunus species not easily resolved by routine analytical methods.
\end{abstract}

\section{Keywords}

Allergens, Melt Analysis, Prunus Speciation, Real-Time PCR

\section{Introduction}

Food allergies, characterised by adverse immunologic (IgE and non-IgE mediated) reactions to food, have po-

"Corresponding author.

How to cite this paper: Nixon, G., Hall, L., Wilkes, T., Walker, M. and Burns, M. (2016) Novel Approach to the Rapid Differentiation of Common Prunus Allergen Species by PCR Product Melt Analysis. Food and Nutrition Sciences, 7, 920-926. 
tentially fatal consequences [1] and have reached epidemic proportions in the industrialised world [2] [3] affecting up to $10 \%$ of young children and $2 \%-3 \%$ of adults. Allergen induced fatal anaphylaxis, though comparatively rare [4], contributes to well-documented detriment to the quality of life for allergic consumers and their families [5]-[7]. Food allergies place additional burdens on national health care systems [8], on businesses (e.g. food recalls) and regulators [9]. Regulatory risk management strategies for allergic consumers have focused on providing information (label declarations) concerning the presence of food allergens occurring as part of the product formulation [10] [11].

In addition to deliberate adulteration, allergenic food components can enter the food chain through accidental cross contamination during harvest, transport, storage, and processing and there should be systems in place to address these risks [12] [13]. A number of incidents were identified in 2014/2015 in relation to cumin and paprika spices apparently contaminated by Prunus species, either almond (Prunus dulcis) or mahaleb, (Prunus mahaleb) [14]-[18]. Prunus is a large genus and includes trees and shrubs, such as almond, plums, cherries, peaches, nectarines, apricots and mahaleb. Several of these important species contain allergenic proteins [19] although only almond is listed in Annex II of EU Regulation 1169/2011, obliging disclosure when used in food [10].

The most common analytical approach for food allergen detection remains enzyme linked immunosorbent assay, ELISA [20], however, it is now well recognised that commercially available ELISA tests exhibit crossreactivity to several Prunus species [18]. Hence, although ELISA represents a good screening test for Prunus species, it must be followed up by more discriminating approaches such as polymerase chain reaction (PCR), or liquid chromatography tandem mass spectrometry, LC-MS/MS [15]. Individual PCR-based assays are typically limited to general or targeted specificities. However, DNA melting curve-based approaches [21] for food allergens developed by researchers such as Costa et al. (2012) [22] show the potential to distinguish between related nut species based on melt characteristics.

We report the development and demonstrate proof of principle for a simple real-time PCR screening approach utilising melting analysis to discriminate between closely related Prunus species. The method was developed in response to an investigation undertaken by the UK Government Chemist [23]. The Government Chemist Programme in LGC has both statutory and advisory functions, and in the latter capacity was asked to look into the possible contamination of spices by potentially allergenic materials, namely Prunus species. The PCR screening approach reported herein will augment the capabilities of both Official Control and food industry laboratories by providing a means to easily differentiate between common Prunus species.

\section{Experimental}

\subsection{Referred Sample}

The sample referred to the Government Chemist for advice and analysis was a commercially available paprika-based sample (assumed to mainly comprise Capsicum annuum), which was suspected of also containing material derived from Prunus species.

\subsection{Materials}

A representative panel of control materials were sourced from commercial suppliers. Standard/smoked ground paprika (Capsicum annuum), organic cumin seeds (Cuminum cyminum), ground mahaleb (Prunus mahaleb) and almond (Prunus dulcis) were purchased from online retailers; apricot stone (Prunus armeniaca, stone taken from whole fruit) and peach stone (Prunus persica, stone taken from whole fruit) were purchased from UK supermarket stores.

Species identity of these control materials were independently confirmed using PCR sequencing primers annealing to the internal transcribed spacer (ITS 2) and ribulose bisphosphate carboxylase long chain (rbcL) regions of the nuclear and chloroplast genomes respectively, followed by Sanger DNA sequencing of the resultant PCR products and sequence confirmation using the Barcode Of Life Database (BOLD) [24] and GenBank ${ }^{\mathbb{B}}$ [25] databases (data not shown).

\subsection{Sample Preparation and DNA Extraction}

Unless pre-ground, the materials were ground to a fine powder using an IKA Tube Mill control (IKA ${ }^{\circledR}$-Werke 
GmbH \& Co. KG, Germany) and DNA extracted from 100 mg samples using a modified CTAB method [26]. Extracted DNA was quantified using a NanoDrop ${ }^{\mathrm{TM}}$ ND-1000 spectrophotometer (Thermo Scientific, UK).

\subsection{Real-Time PCR}

A general Prunus species real-time PCR-based assay was adapted from a published Prunus mahaleb specific assay [14] targeting the conserved internal transcribed space (ITS) region of Prunus species using a Prunus mahaleb ITS sequence (\#JQ776826) representative of the genus. The assay was developed using Primer Express 3.0.1 (Life Technologies, Paisley, UK) under standard "Taqman ${ }^{\circledR}$ Quantitation" type assay design parameters and specificity evaluated using Primer-BLAST [27].

Twenty-five $\mu 1$ reactions were prepared comprising $12.5 \mu \mathrm{l} 2$ x Fast Plus EvaGreen ${ }^{\circledR}$ qPCR Master Mix, High ROX ${ }^{\mathrm{TM}}$ (Biotium, Inc., Hayward, USA), 900 nM PRU_ITS_FWD1 (5'-TAGCAGAACGACCCGAGAACTAG-3') forward and $900 \mathrm{nM}$ PRU_ITS_REV1 (5'-CGCCGGTGTTCGTTTGTAC-3') reverse primers. HPLC purified primers were sourced from Eurofins Genomics (Ebersberg, Germany). The reactions were made up to $20 \mu \mathrm{l}$ with DNase/DNA-free water (Ambion brand, Life Technologies, Paisley, UK) and $5 \mu$ lof the template $\mathrm{DNA} /$ water control was added to each reaction as appropriate, to bring the total volume to $25 \mu$. Template DNA input was normalised (where possible) to $50 \mathrm{ng}$ for each test sample.

Real-time PCR was performed under 2-step thermal cycling conditions $\left(10 \mathrm{~min} / 95^{\circ} \mathrm{C} ; 15 \mathrm{~s} / 95^{\circ} \mathrm{C}, 1 \mathrm{~min} / 60^{\circ} \mathrm{C}\right.$, 45 cycles) incorporating a melt analysis step $\left(15 \mathrm{~s} / 95^{\circ} \mathrm{C} ; 60^{\circ} \mathrm{C}\right.$ to $95^{\circ} \mathrm{C}, 1.75^{\circ} \mathrm{C} /$ minute ramp rate) using a 7900HT Fast Real-Time PCR System (Life Technologies, Paisley, UK) set to monitor FAM-based fluorescence. The data was analysed using SDS 2.4.1 software (Life Technologies, Paisley, UK) using automated baseline and threshold settings.

\section{Results and Discussion}

\subsection{Assay Development}

The melt analysis methodology was adapted from an in-house developed hydrolysis probe-based real-time PCR assay [14] targeting the Prunus mahaleb internal transcribed spacer (ITS) sequence (GenBank\#JQ776826). GenBank $^{\circledR}$ [25] Entrez Nucleotide sequence database searches and ClustalW [28] alignments showed conserved and variable regions with related Prunus species which supported the application of the assay to species differentiation by melt analysis.

\subsection{Preliminary Evaluation and Test Sample Analysis}

A preliminary evaluation study was conducted that challenged the DNA-binding dye-based real-time PCR assay with a panel of commonly found Prunus species, cumin and paprika control materials, and a paprika-based commercial sample referred to the UK Government Chemist for further analysis. Immunological methods comprising several ELISA commercial kits, indicated the presence of an unidentified Prunus species within the referred sample at an approximate concentration of $500 \mathrm{mg} \mathrm{kg}^{-1}$ expressed as almond (data not shown).

Our results demonstrate that the real-time PCR assay described herein is capable of detecting the Prunus species mahaleb, almond, apricot and peach and generates melt profiles capable of distinguishing between these species (Figure 1(a) and Table 1). The paprika-based referred sample generated a positive amplification response as shown by $\sim 24 \mathrm{Cq}$ value (Table 1) and a well-defined multiple melt peak profile (Figure 1(d)). The second peak $\left(\sim 88^{\circ} \mathrm{C}\right)$ most closely matched almond DNA due to the similarity of $\mathrm{T}_{\mathrm{m}}$ values. Analysis of the $10 \%$ $\mathrm{w} / \mathrm{w}$ mahaleb/almond in paprika DNA admixtures strongly supports this conclusion as the primary peak (consistent with almond) shows a mean $\mathrm{T}_{\mathrm{m}} 88.07^{\circ} \mathrm{C}$ (Table 1 and Figure $1(\mathrm{~d})$ ) which is identical to the minor peak observed in the referred paprika sample with overlapping confidence intervals.

However the lower $\mathrm{T}_{\mathrm{m}}$ melt peak $\left(\sim 82.6^{\circ} \mathrm{C}\right)$ does not appear to correlate with any of the tested Prunus control materials within this study and appears to represent a slightly higher concentration than that of the almond present. Hence, a primary unidentified peak has also been observed in the melt profile of the referred paprika sample that is indicative of a Prunus species that was unrecognised by immunological analysis, and which requires further study to fully characterise. In-silico analysis of the ITS region, also borne out through the experimental work, indicated that this primary peak is unlikely to arise as a result of multiple copies of the ITS region. Clonal sequencing of this primary peak may provide further information on the nature of the product and if this pertains to a particular Prunus species. However, this was not investigated further as part of the current study, 


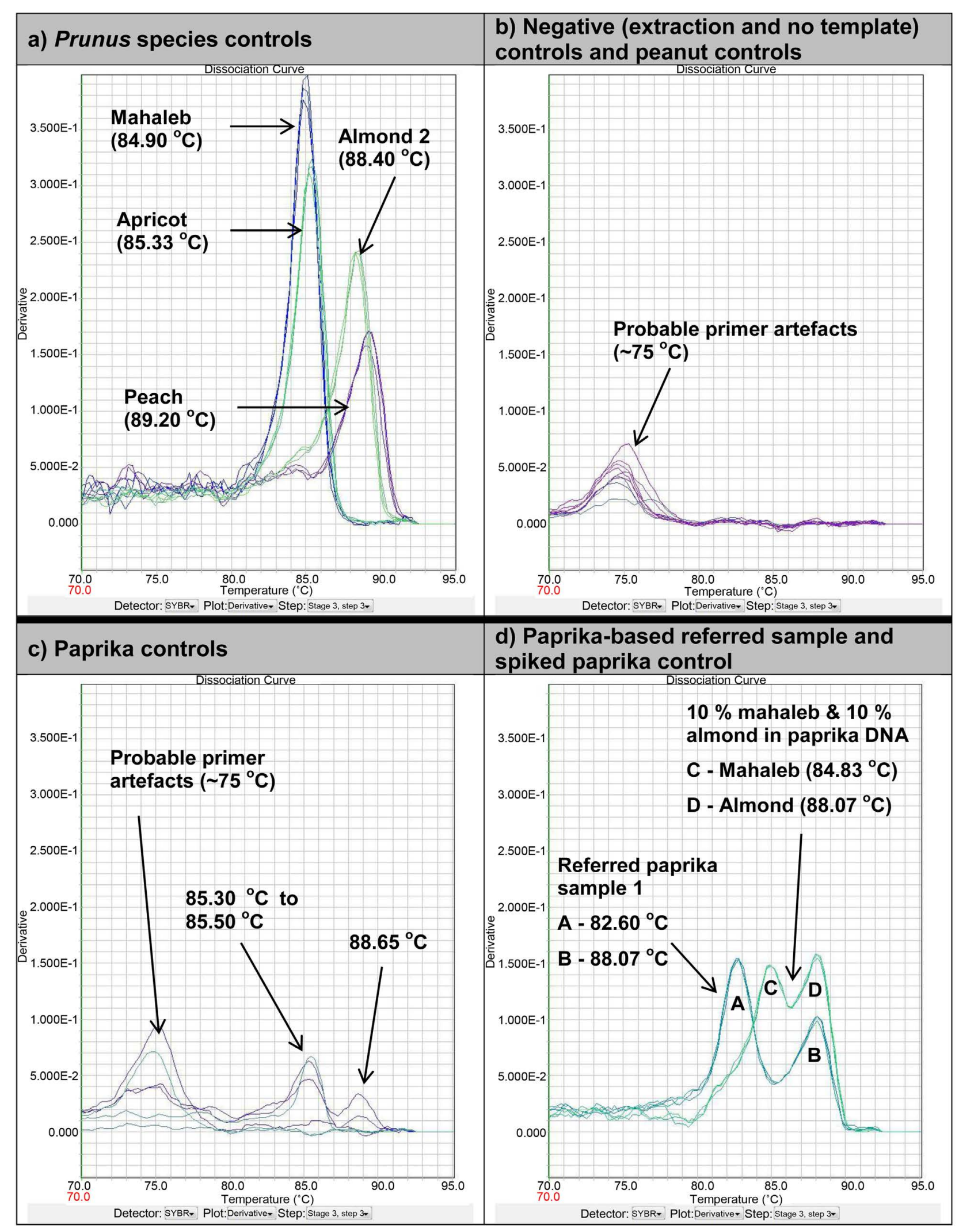

Figure 1. Melt profiles for selected control and test materials (triplicate technical replicates). Key peaks highlighted and associated mean $\mathrm{T}_{\mathrm{m}}$ values shown. 
Table 1. Table showing amplification and melt peak $\mathrm{T}_{\mathrm{m}}$ data generated using Prunus $\mathrm{qPCR}$ assay for selected control and test materials. Mean $\mathrm{C}_{\mathrm{a}}$ and $\mathrm{T}_{\mathrm{m}}$ results are derived from at least triplicate technical replicates. Main melt peaks are highlighted in bold along with an estimate of the $95 \%$ confidence interval associated with these. "*" denotes probable primer artefact and " 1 " denotes irregular detection of the peak (one or two/two of the three technical replicates).

\begin{tabular}{|c|c|c|c|c|}
\hline Sample & Mean $C_{q}$ & Mean Peak $1 T_{m}$ & Mean Peak $2 T_{m}$ & Mean Peak $3 T_{m}$ \\
\hline Mahaleb & 12.57 & $84.90 \pm 0.35$ & & \\
\hline Apricot & 12.46 & $85.33 \pm 0.23$ & v & \\
\hline Peach & 18.93 & $89.20 \pm 0.00$ & & \\
\hline Almond & 11.22 & $88.40 \pm 0.35$ & & \\
\hline Peanut & 38.51 & $74.50^{*}$ & & \\
\hline Paprika & 35.19 & $74.93^{*}$ & $85.30^{1}$ & $88.65^{1}$ \\
\hline Smoked paprika & 36.89 & $74.90^{*}$ & $85.50^{1}$ & \\
\hline Cumin seeds & 32.26 & $75.35^{*}$ & $85.37 \pm 0.23$ & 88.40 \\
\hline Paprika-based referred sample & 24.12 & $82.67 \pm 0.26$ & $88.04 \pm 0.14$ & \\
\hline $10 \%$ mahaleb \& $10 \%$ almond in paprika DNA & 13.92 & $84.83 \pm 0.23$ & $88.07 \pm 0.12$ & \\
\hline Extraction control & 37.65 & $75.03^{*}$ & & \\
\hline No Template Control & 37.80 & $74.63^{*}$ & & \\
\hline
\end{tabular}

which had already shown the paprika-based sample to be non-compliant with relevant food labelling legislation as there was a very high likelihood that it contained almond which was not listed as an ingredient.

As is often observed in DNA-binding dye-based real-time PCR assays, the negative extraction and negative template controls showed late amplification $\left(>37\right.$ cycles) and poor low $\mathrm{T}_{\mathrm{m}}$ peaks $\left(\sim 75^{\circ} \mathrm{C}\right)$ that are characteristic of primer artefact features, particularly primer-dimerisation (Figure 1(b)) [29]. These primer artefacts are absent when sufficient Prunus template DNA is provided in a sample, as evidenced by the controls of mahaleb, apricot, peach and almond, and the primer artefacts are also absent in the referred sample and the $10 \% \mathrm{w} / \mathrm{w}$ mahaleb/almond in paprika DNA sample.

Paprika and cumin control materials were included as comparators for the paprika-based referred sample and showed late amplification (Table 1). These paprika and cumin control samples also demonstrated some evidence for low melt peaks characteristic of primer artefacts (Table 1 and Figure 1(c)). The low level multiple peaks observed around the $85^{\circ} \mathrm{C}$ and $88^{\circ} \mathrm{C}$ regions were inconsistently formed and represent possible trace levels of amplifiable targets. These may be potentially due to either limited assay specificity issues or more likely the presence of trace Prunus species contamination in the control samples because of the manufacturing/processing techniques typically used in spice manufacture. The $\mathrm{C}_{\mathrm{q}}$ values and the magnitude of these melt peaks (when observed) are lower in the paprika and cumin control samples compared to the Prunus control materials and the referred sample, further reinforcing the possible trace level detection of these elements. The peanut control material showed characteristic primer artefacts but no evidence of other melt peaks, further supporting the premise that a lack of Prunus template DNA often produces observable primer artefacts.

The results indicate that a melt profile has been generated from the paprika-based referred sample which is consistent with almond being present. A second Prunus like species has been detected (estimated to be at a higher concentration to the potential almond content), whose profile is not consistent with the control materials used to represent the species of mahaleb, almond, peach or apricot in the current study. In addition, the study highlights the potential trace contamination of spices with non-labelled Prunus species such as almond which may represent an allergenic risk to certain individuals and warrants further investigation to determine the scale of the issue.

\section{Conclusion}

Analysis for food allergens and food authenticity is particularly challenging for closely related commercial Prunus species, such as Prunus dulcis (almond) and Prunus mahaleb (mahaleb) which can cross-react with existing immunological tests or are not routinely tested for and therefore escape detection. The methodology de- 
veloped within this preliminary study provides analysts with a single real-time PCR-based test that can screen for multiple Prunus species and provide putative identification. Hence, this DNA melt curve screening assay augments the diagnostic toolkit available to the food industry and regulatory authorities. Subject to further validation, this method has the potential to simply resolve Prunus positive ELISA findings and reduce the incidence of undeclared Prunus species entering the food chain and posing a risk for those with food allergies.

\section{Acknowledgements}

The authors gratefully acknowledge funding through the UK Department for Business, Innovation \& Skills as part of the Government Chemist Programme 2014-2017, and from the UK Food Standards Agency.

\section{References}

[1] Muraro, A., Werfel, T., Hoffmann-Sommergruber, K., Roberts, G., Beyer, K., Bindslev-Jensen, C., Cardona, V., Dubois, A., duToit, G., Eigenmann, P., Fernandez Rivas, M., Halken, S., Hickstein, L., Host, A., Knol, E., Lack, G., Marchisotto, M.J., Niggemann, B., Nwaru, B.I., Papadopoulos, N.G., Poulsen, L.K., Santos, A.F., Skypala, I., Schoepfer, A., Van Ree, R., Venter, C., Worm, M., Vlieg-Boerstra, B., Panesar, S., de Silva, D., Soares-Weiser, K., Sheikh, A., Ballmer-Weber, B.K., Nilsson, C., de Jong N.W., Akdis, C.A., Allergy, E.F. and Anaphylaxis Guidelines, G. (2014) EAACI Food Allergy and Anaphylaxis Guidelines: Diagnosis and Management of Food Allergy. Allergy, 69, 1008-1025. http://dx.doi.org/10.1111/all.12429

[2] Prescott, S. and Allen, K.J. (2011) Food Allergy: Riding the Second Wave of the Allergy Epidemic. Pediatric Allergy and Immunology, 22, 155-160. http://dx.doi.org/10.1111/j.1399-3038.2011.01145.x

[3] Sicherer, S.H. and Sampson, H.A. (2014) Food Allergy: Epidemiology, Pathogenesis, Diagnosis, and Treatment. Journal of Allergy and Clinical Immunology, 133, 291-307. http://dx.doi.org/10.1016/j.jaci.2013.11.020

[4] Umasunthar, T., Leonardi-Bee, J., Hodes, M., Turner, P.J., Gore, C., Habibi, P., Warner, J.O. and Boyle, R.J. (2013) Incidence of Fatal Food Anaphylaxis in People with Food Allergy: A Systematic Review and Meta-Analysis. Clinical \& Experimental Allergy, 43, 1333-1341. http://dx.doi.org/10.1111/cea.12211

[5] Avery, N.J., King, R.M., Knight, S. and Hourihane, J.O. (2003) Assessment of Quality of Life in Children with Peanut Allergy. Pediatric Allergy and Immunology, 14, 378-382. http://dx.doi.org/10.1034/j.1399-3038.2003.00072.x

[6] King, R.M., Knibb, R.C. and Hourihane, J.O. (2009) Impact of Peanut Allergy on Quality of Life, Stress and Anxiety in the Family. Allergy, 64, 461-468. http://dx.doi.org/10.1111/j.1398-9995.2008.01843.x

[7] Venter, C., Sommer, I., Moonesinghe, H., Grundy, J., Glasbey, G., Patil, V. and Dean, T. (2015) Health-Related Quality of Life in Children with Perceived and Diagnosed Food Hypersensitivity. Pediatric Allergy and Immunology, 26, 126-132. http://dx.doi.org/10.1111/pai.12337

[8] Gibbison, B., Sheikh, A., McShane, P., Haddow, C. and Soar, J. (2012) Anaphylaxis Admissions to UK Critical Care Units between 2005 and 2009. Anaesthesia, 67, 833-839. http://dx.doi.org/10.1111/j.1365-2044.2012.07159.x

[9] Madsen, C.B., Hattersley, S., Allen, K.J., Beyer, K., Chan, C.H., Godefroy, S.B., Hodgson, R., Mills, E.N., MunozFurlong, A., Schnadt, S., Ward, R., Wickman, M. and Crevel, R. (2012) Can We Define a Tolerable Level of Risk in Food Allergy? Report from a EuroPrevall/UK Food Standards Agency Workshop. Clinical \& Experimental Allergy, 42, 30-37. http://dx.doi.org/10.1111/j.1365-2222.2011.03868.x

[10] European Parliament and the Council of the European Union (2011) Regulation (EU) No. 1169/2011 of the European Parliament \& of the Council of 25 October 2011 on the Provision of Food Information to Consumers. Official Journal of the European Union, 304, 18-63.

[11] Gendel, S.M. (2012) Comparison of International Food Allergen Labeling Regulations. Regulatory Toxicology and Pharmacology, 63, 279-285. http://dx.doi.org/10.1016/j.yrtph.2012.04.007

[12] British Retail Consortium (2015) BRC Global Standard for Food Safety Issue 7. http://www.brcglobalstandards.com/Manufacturers/Food/FoodIssue7.aspx

[13] Manning, L. (2013) Food and Drink: Good Manufacturing Practice: A Guide to Its Responsible Management. 6th Edition, Wiley-Blackwell, Hoboken.

[14] Burns, M., Walker, M., Wilkes, T., Hall, L., Gray, K. and Nixon, G. (2016) Development of a Real-Time PCR Approach for the Specific Detection of Prunus mahaleb DNA. Food and Nutrition Sciences, 7, 703-710. http://dx.doi.org/10.4236/fns.2016.78071

[15] Government Chemist (2015) Paprika Referee Sample: Further Testing Identifies Almond Present. https://www.gov.uk/government/news/paprika-referee-sample-further-testing-identifies-almond-present

[16] Government Chemist and Food Standards Agency (2015) Cumin Analysis: DNA Test for Mahaleb Developed. https://www.gov.uk/government/news/cumin-analysis-dna-test-for-mahaleb-developed 
[17] The Seasoning and Spice Association (2015) The Seasoning and Spice Association. Q\&A on Undeclared Peanut/Almond Protein. http://www.seasoningandspice.org.uk/publicgeneral/QandA.pdf

[18] Walker, M.J., Burns, D.T., Elliott, C.T., Gowland, M.H. and Mills, E.N.C. (2016) Is Food Allergen Analysis Flawed? Health and Supply Chain Risks and a Proposed Framework to Address Urgent Analytical Needs. Analyst, 141, 24-35. http://dx.doi.org/10.1039/C5AN01457C

[19] Chen, L., Zhang, S., Illa, E., Song, L., Wu, S., Howad, W., Arús, P., Wegvd, E., Chen, K. and Gao, Z. (2008) Genomic Characterization of Putative Allergen Genes in Peach/Almond and Their Synteny with Apple. BMC Genomics, 9, 543. http://dx.doi.org/10.1186/1471-2164-9-543

[20] Engvall, E. and Perlmann, P. (1971) Enzyme-Linked Immunosorbent Assay (ELISA) Quantitative Assay of Immunoglobulin G. Immunochemistry, 8, 871-874. http://dx.doi.org/10.1016/0019-2791(71)90454-X

[21] Ririe, K.M., Rasmussen, R.P. and Wittwer, C.T. (1997) Product Differentiation by Analysis of DNA Melting Curves during the Polymerase Chain Reaction. Analytical Biochemistry, 245, 154-160. http://dx.doi.org/10.1006/abio.1996.9916

[22] Costa, J., Mafra, I. and Oliveira, M.B.P.P. (2012) High Resolution Melting Analysis as a New Approach to Detect Almond DNA Encoding for Pru du 5 Allergen in Foods. Food Chemistry, 133, 1062-1069. http://dx.doi.org/10.1016/j.foodchem.2012.01.077

[23] Government Chemist (2016) About Us. Government Chemist. https:/www.gov.uk/government/organisations/government-chemist/about

[24] Ratnasingham, S. and Hebert, P.D. (2007) Bold: The Barcode of Life Data System. Molecular Ecology Notes, 7, 355364. http://www.barcodinglife.org http://dx.doi.org/10.1111/j.1471-8286.2007.01678.x

[25] Benson, D.A., Karsch-Mizrachi, I., Lipman, D.J., Ostell, J. and Wheeler, D.L. (2005) GenBank. Nucleic Acids Research, 33, D34-D38. http://dx.doi.org/10.1093/nar/gki063

[26] Lipp, M., Brodmann, P., Pietsch, K., Pauwels, J., Anklam, E., Borchers, T., Braunschweiger, G., Busch, U., Eklund, E., Eriksen, F.D., Fagan, J., Fellinger, A., Gaugitsch, H., Hayes, D., Hertel, C., Hortner, H., Joudrier, P., Kruse, L., Meyer, R., Miraglia, M., Muller, W., Phillipp, P., Popping, B., Rentsch, R., Wurtz, A., et al. (1999) IUPAC Collaborative Trial Study of a Method to Detect Genetically Modified Soy Beans and Maize in Dried Powder. Journal of AOAC International, 82, 923-928.

[27] Ye, J., Coulouris, G., Zaretskaya, I., Cutcutache, I., Rozen, S. and Madden, T.L. (2012) Primer-BLAST: A Tool to Design Target-Specific Primers for Polymerase Chain Reaction. BMC Bioinformatics, 13, 134. http://dx.doi.org/10.1186/1471-2105-13-134

[28] Thompson, J.D., Higgins, D.G. and Gibson, T.J. (1994) CLUSTAL W: Improving the Sensitivity of Progressive Multiple Sequence Alignment through Sequence Weighting, Position-Specific Gap Penalties and Weight Matrix Choice. Nucleic Acids Research, 22, 4673-4680. http://dx.doi.org/10.1093/nar/22.22.4673

[29] Rasmussen, R., Morrison, T., Herrmann, M. and Wittwer, C. (1998) Quantitative PCR by Continuous Fluorescence Monitoring of a Double Strand DNA Specific Binding Dye. Biochemistry, 2, 11.

\section{Submit or recommend next manuscript to SCIRP and we will provide best service for you:}

Accepting pre-submission inquiries through Email, Facebook, LinkedIn, Twitter, etc.

A wide selection of journals (inclusive of 9 subjects, more than 200 journals)

Providing 24-hour high-quality service

User-friendly online submission system

Fair and swift peer-review system

Efficient typesetting and proofreading procedure

Display of the result of downloads and visits, as well as the number of cited articles

Maximum dissemination of your research work

Submit your manuscript at: http://papersubmission.scirp.org/ 